\title{
Effects of irrigation solutions and Calcium hydroxide dressing on root canal treatments of periapical lesions
}

\author{
Vita Nirmala \\ Department of Conservative Dentistry \\ Faculty of Dentistry Gadjah Mada University \\ Yogyakarta - Indonesia
}

\begin{abstract}
The preparation of root canal in endodontic treatment plays an important role in treating non vital teeth with periapical lesion. Some factors influence the success of root canal treatment in short and long terms are the irrigation of root canal using antiseptic solution and the use of root canal medicament. The aim of this literature study is to determined the effect of irrigation solution and Calcium hydroxide dressing in root canal treatment of periapical lesions. The use of root canal medicament during the endodontic treatment could sterilized and decreased the number of pathogenic microorganism of root canal. An effective root canal irrigation solution must be able to dissolve organic and anorganic debris, lubricate endodontic instruments, disinfect microorganisms, non toxic and economical. The best irrigation solution has maximum antimicrobial effect with minimum toxicity. Division of calcium hydroxide into Calcium and hydroxyl ions is responsible for alkalinization of cavity, subsequently it makes the condition of cavity to be inappropriate for bacterial endotoxin in vitro as well as in vivo, and considered as the only clinically effective medicament in inactivating bacterial endotoxin. Calcium hydroxide is the only medication which has the ability to clinically inactive bacterial endotoxin in vitro in vivo and accepted as the best of root canal medication.
\end{abstract}

Key words: root canal treatment, irrigation solutions, Calcium hydroxide dressing, periapical lesion

Correspondence: Vita Nirmala, c/o: Bagian Ilmu Konservasi Gigi, Fakultas Kedokteran Gigi Universitas Gadjah Mada. Jln. Sekip Utara, Yogyakarta 55281, Indonesia. Telp. 0274-547130.

\section{INTRODUCTION}

The preparation of root canal in endodontic treatment plays an important role in treating non vital teeth with periapical lesion. The bacteria are not only causing the periapical lesion but also play role in the defense mechanism of the lesion. ${ }^{1,2}$ The infected root canal must be taken using endodontic instruments and cleaned with antiseptic irrigation solution.

The root canal medicaments are a part of root canal treatment and play an important part in the success of endodontic treatment. Some factors influence the success of root canal treatment in short and long terms are the irrigation of root canal using antiseptic solution and the use of root canal medicament. The use of root canal medicament during the endodontic treatment could sterilized and decreased the number of pathogenic microorganism of root canal. Georgopoulou et al. ${ }^{4}$ reported that root canal medicaments reduced or eliminated microorganism in root canal. Root canal irrigation is one stage of endodontic treatment which is essential, neglecting it will cause treatment failure. The irrigation must be done after root canal preparation to remove the remaining infected pulp tissue and dentin. The cleaness of root canal is influenced by effective irrigation. ${ }^{3}$ The effectivity of irrigation depends on the quantity of irrigation solution, root canal diameter, and pulp condition. In pulpless teeth the irrigation solution not only entering the entire root canal but also penetrate into periapical. ${ }^{3}$ Root canal medicament is still needed since the irrigation using sodium hypochlorite $5 \%$ and hydrogen peroxide $3 \%$ after root canal biomechanic preparation could not reduce or eliminate all root canal microorganism. Chlorhexidine digluconate is recommended for root canal irrigation of infected teeth. It has antimicrobial effect and absorption of hard tissue in therapeutic level, which is called substantivity effect.4,5 Root canal dressing is used in the teeth with periapical lesion for root canal disinfection after biomechanical preparation. For one visit obturation, it is recommended to use irrigation solution with bactericidal effect.

Calcium hydroxide has been used in conservative dentistry since Nygren in 1838.2,6 In 1930, calcium hydroxide was used as pulp capping material for the first time but it was not been publicized. ${ }^{2,7}$ Calcium hydroxide in the market is sold in various forms i.e. powder mixed with water, saline solution, methyl cellulose, glycerin and paste form. In paste form, there are Calcium hydroxide with methyl cellulose (Pulpadent), Calcium hydroxide powder in ringer solution (Calxyl), mixed paste (Dycal), tube paste or syringe paste, and in point form (Calcium hydroxide Plus Points) which recently available in dental market.

The aim of this literature study is to determined the effect of irrigation solution and calcium hydroxide dressing in root canal treatment of periapical lesion. 


\section{Root canal irrigation solution}

An effective root canal irrigation solution must be able to dissolve organic and anorganic debris, lubricate endodontic instruments, disinfect microorganisms, non toxic and economical. ${ }^{8}$ The best irrigation solution has maximum antimicrobial effect with minimum toxicity. Anusavice ${ }^{9}$ stated that all dental materials must have oral biocompatibility. All dental materials must be harmless for pulp and soft tissue, have no systemic effect if it absorp or diffuse in body circulation, free allergen, and have no carcinogenic potential. The irrigation solution which common used in endodontic treatment has antiseptic effect on microorganisms in vitro and in vivo. The effectivity and toxicity of irrigation solution depend on the concentration, temperature and time. ${ }^{10,11}$ The irrigation solutions for root canal treatment are:

\section{Halogen group}

Chlorine $(\mathrm{NaOCl} 5 \%)$ has some effects i.e. lubricant, pulp tissue solvent, whitening, and strong antiseptic. ${ }^{3}$ Chlorine also has an adverse effect, it can not dissolve anorganic debris, 1/3 apical region unreachable, corrosive on carbon steel endodontic instruments, and toxic.

Iodofor, an organic solution containing iodine. This material could be used for cleaning root canal, since it has low surface tension, antiseptic effect, less toxic than $\mathrm{NaOCl}$, and not causing allergic reaction. The unwanted characteristic of iodofor is that its toxicity ten times greater than its antimicrobial effect, and irritates oral tissue, i.e. Wescodyne, Iodopax, Iodine potassium iodide.

\section{Detergent group}

The use of detergent in irrigation solution could make the root canal cleaner since it could dissolve the remaining lipid. ${ }^{12}$ The effectivity of detergent in cleaning root canal due to its active surface tension, binding the organism and organic debris, so that it could be disposed from root canal. The mechanism of its antibacterial effect is by way of disturbing cell membrane lipoprotein, but weaker than $\mathrm{NaOCl} .{ }^{13,14}$

Irrigation substance belonging to cationic detergent is quartenary ammonium compound group. Although it has good cleansing effect, it is not an ideal irrigation solution due to its low antibacterial effect, can inhibit and prolong wound healing process. ${ }^{14,15}$ The cationic detergents are: EDTAC, Zephiran, Salvizol.

Irrigation solution belonging to anionic detergent (nonionic) among others are lauryl sulphate and soap. A combination of Calcium hydroxide with lauryldiethylene-glycol-ether-sodium-sulphate $10 \%$ and $20 \%$ has antibacterial effect higher than calcium hydroxide solution on Streptococcus faecalis, Streptococcus salivarius, Neisseria sp, Iphteroid, Staphylococcus aureus, Lactobacillus sp, Staphylococcus epidermidis, Bacillus subtilis and Candida albicans. ${ }^{15}$

\section{Chelating solution}

Chelating solution is a material used to declassify narrow root canals. Common solutions used are usually acidic type such as EDTA, citric acid, ${ }^{16}$ lactic acid, sulphuric acid, and tannic acid. Other solutions are EDTAC, RC-Prap Salvizol, ${ }^{15}$ Salvidont. ${ }^{17}$

\section{Calcium hydroxide dressing in inactivating bacterial endotoxin}

First reference, ${ }^{18}$ the use of Calcium hydroxide in 1938 , later was developed after Hermann's research, ${ }^{19}$ in 1920. Calcium hydroxide has high alkali $\mathrm{pH}$, very frequently used at dental clinics for direct pulp protection, pulpotomy of deciduous and permanent teeth, root canal dressing in permanent dental care with uncompleted rhizogenesis, root canal filling sealer, root perforation, dental resorption and intracanal antiseptic dressing. ${ }^{20}$ The application is much related to antibacterial activities, ${ }^{4,21,22}$ biocompatibility, ${ }^{5,22}$ hygroscopic, ability to reduce periapical tissue exudates, and its capacity to accelerate mineralization. ${ }^{23,24}$ It can dissolve necrotic tissue after biomechanics preparation, and it can act as bacterial substrate leading to stimulation of apical and periapical dental reparation with chronic lesion.

Among endodontic treatment dressings with non vital pulp and periapical lesion, Calcium hydroxide is utilized for its proven bactericidal effect and its capacity to neutralize bacterial endotoxin. Division of Calcium hydroxide into Calcium and hydroxyl ions is responsible for alkalinization of cavity, subsequently it makes the condition of cavity to be inappropriate for bacterial growth and proliferation. Calen paste, one of Calcium hydroxide paste with few CP (camphorated paramono chlorophenol), has produced excellent result in teeth with periapical lesion. ${ }^{20}$

Recent spotlight in endodontic treatment is dental care with necrotic pulp and periapical lesion, for the fact that higher rate of treatment failure compared to treatment towards no periapical lesion. In dental with chronic periapical lesion, there is a bigger prevalence of anaerob bacteria hiding inside all root canal system (dentinal tubules, apical craters, cementum lacuna) including apical bacteria biofilm, due to the fact that these areas cannot be reached by instruments, therefore, intracanal dressing is recommended to help eliminate bacteria and to improve the possibility of successful treatment in dental clinics. $^{23,25,26,27}$

According to Leonardo et al., ${ }^{28}$ teeth, with or without periapical lesion has different pathologic bacteria that requires different dental treatment. In cases with periapical lesion, it requires root canal dressing during inter session treatment, for the reason that the success of periapical lesion treatment is related directly to bacterial cleansing, product and subproduct of root canal system. Root canal treatment procedure and medicament are not only bactericidal, but also creating the inactivation of bacterial endotoxin. 
Lacked of information on intracanal dressing effect towards bacterial endotoxin residues which can attach to mineralization tissue, ${ }^{29}$ had made Safavi and Nicholas ${ }^{30}$ evaluated in vitro the effect of Calcium hydroxide on bacterial endotoxin. They concluded that Calcium hydroxide hydrolyzed high toxic Lipid A molecule which was responsible for damaging endotoxin. In their further study, Safavi and Nicholas ${ }^{23}$ concluded that Calcium hydroxide transformed Lipid A to become fatty acid and amino sugar belonging to non toxic component. This result was renewed by Barthel et al. ${ }^{31}$ and Olsen et al. ${ }^{31}$ who reported Calcium hydroxide ability to detoxicate bacterial endotoxin in vitro.

In 2002, Nelson-Filho et al. ${ }^{26} \mathrm{did}$ an in vivo research to evaluate radiographically, the effect of endotoxin with calcium hydroxide application in apical and periapical tissue of dog teeth. They observed that endotoxin caused periapical lesion after 30 days and that calcium hydroxide inactivated bacterial endotoxin. Silva et al. ${ }^{20}$ analyzed histopathologically all dog teeth apical and periapical tissues, where it was filled with bacterial endotoxin and Calcium hydroxide. They reported that endotoxin caused periapical lesion, and calcium hydroxide detoxicated endotoxin in vivo.

Jiang et al..$^{32}$ also evaluated the direct effect of bacterial endotoxin on osteoclastogenesis and the capacity of Calcium hydroxide to inhibit osteoclast forming, stimulated by endotoxin. They reported that calcium hydroxide significantly reduced osteoclast differentiation. This new finding has renewed the concept of root canal dressing, in pertaining to Calcium hydroxide not only as the best medicament but fundamentally as the one and only medication which has the ability to inactivate endotoxin found in root canal system with necrotic pulp and chronic periapical lesion.

\section{DISCUSSION}

According to histopathology result, apical and periapical tissue healing is better in teeth with root canal dressing compared with group with direct obturation. The group applying root canal dressing produces tighter apical closure, creating non intens periapical inflammation reaction, emphasizing the importance of root canal dressing in endodontic treatment for necrotic pulp and periapical lesion. Other study reported how essential root canal dressing for eliminating bacteria from root canal and apical surface areas. ${ }^{20}$

Sodium hypochlorite is commonly used as root canal irrigation solution in dental treatment with necrotic pulp with or without periapical lesion. The high concentrated sodium hypochlorite solution has potent antimicrobial action. This sodium hypochlorite is recommended for dental care with periapical lesion. ${ }^{23}$

Bacterial endotoxin is a component of gram-negative bacterial cell wall, found in all teeth with necrotic pulp and chronic periapical lesion, seen radiographically. Bacterial endotoxin holds a fundamental role in genesis and periapical lesion endurance, caused by inflammation induction and bone resorption. Among dressing for dental non vital pulp endodontic treatment with chronic periapical lesion, Calcium hydroxide is used for its proven bactericidal effect and its capacity to neutralize bacterial endotoxin. Division of Calcium hydroxide into Calcium and hydroxyl ions is responsible for alkalinization of cavity, subsequently it makes the condition of cavity to be inappropriate for bacterial growth and proliferation. ${ }^{23,24}$ Root canal irrigation solutions must be able to dissolve organic and anorganic debris, lubricate endodontic instruments, disinfect microorganisms, non-toxic and economical. The most effective irrigation solution is one that has maximal antimicrobial capacity and minimal toxicity. The most effective irrigation solution is one that has maximal antimicrobial capacity and minimal toxicity. Sodium hypochlorite is recommended for dental care with periapical lesion ${ }^{30}$ due to its higher effectivity compared to liquefied solution and the low surface tension is important for root canal cleansing. Calcium hydroxide inactivated toxic effect of bacterial endotoxin in vitro and in vivo and accepted not only as the best medicament but fundamentally as the one and only medication which has the ability to clinically inactivate bacterial endotoxin.

\section{REFERENCES}

1. Leonardo MR, Almeida WA, da Silva LA, Utrilla LS Histopathological observations of periapical repair in teeth with radiolucent areas submitted to two different methods of root canal treatment. J Endod 1995 Mar; 21(3):137-41.

2. Martin DM, Crabb HSM. Calcium hydroxide in root canal therapy. Brit Dent J 1977; 277-83.

3. Grossman LI. Ilmu endodontik dalam praktek. $11^{\text {st }} \mathrm{ed}$. Seymour Oliet, Carlos E, Del Rio. Rafiah A, Suryo S, editor. Jakarta: Penerbit EGC; 1995. p. 248.

4. Georgopoulou M, Kotakiotis E, Nakou M. In vitro evaluation of the effectiveness of calcium hydroxide and paramonochlorophenol on bacteria from the root canal. Endod Dent Traumatol 1993; Dec; 9(6):249-53.

5. Holland R, Souza V. Tratamento conservador da polpa dental. In: Leonardo MR, Leal JM, editors. Endodontia: tratamento de canals radiculares. San Paulo: Ed Medica Panamericana; 1998. p. 63-75.

6. Delany GM, Patterson, SS, Miller MS, Newton CW. The effect of chlorexidine gluconate irrigation on the root canal flora of freshly extracted necrotic teeth. Oral Surg Oral Med Oral Pathol 1982 May; 53(5):518-23.

7. Sidharta W. Perawatan saluran akar konvensional pada gigi non vital dengan kelainan periapikal lanjut menggunakan kalsium hidroksida (Laporan kasus). J Ked Gigi UI 1997; Edisi khusus KPPIKG XI: 4.

8. Harty FJ. Endodontik klinis (Clinical endodontics). Yuwono L. Edisi ke-3. Jakarta: Hipokrates; 1993. p. 128.

9. Anusavice KJ. Philip's science of dental materials. $10^{\text {th }}$ ed. Philadelphia: WB Saunders Company; 1996. p. 75-9.

10. Kennedy WA, Walker III WA, Gough RW. Smear layer removal effects on apical leakage. J Endod 1996; 12:21-7.

11. Siswandono, Soekardjo B. Kimia medisinal. Cetakan I. Surabaya: Airlangga University Press; 1995. p. 247-8.

12. Barbosa SV, Spangberg LSW, Almeida D. Low surface tension calcium hydroxide solution is an effective antiseptic. Int Endod J 1994 Jan; 27(1):6-10. 
13. Kolstad R, White RR. Disinfection and sterilization. In: Willett NP, White RR, Rosen S, editors. Essential dental microbiology. New Jersey: Prentice-Hall Int Inc; 1995. p. 57-61.

14. Weine FS. Endodontic therapy. $3^{\text {rd }}$ ed. St Louis: The CV Mosby Co; 1985. p. 317-22.

15. Spangberg L. Intracanal medication. In: Ingle Jl, Bakland LK, editors Endodontics. $4^{\text {th }}$ ed. Philadelphia: Lea \& Febiger; 1994. p. 632-7.

16. Yamaguchi M, Yoshida K, Suzuki R, Nakamura H. Root cana irrigation with citric acid solution. J Endod 1996 Jan; 22(1):27-9.

17. Spangberg L, Pascon EA, Kaufman AY, Safavi K. Tissue irritating properties of bis-dequalinium acetat solutions for endodontic use. J Endod 1988; 14:88-97.

18. Nygreen JA. Radgivare angaende basta sttet att varda och levara tandernas friskhet apud Martin DM, Crabb HSM. Calcium hydroxide in root canal therapy. A review. Br Dent J 1977 May 3; 142(9): 277-83.

19. Hermann BW. Calcium hydroxide as mitted zin behandeed und fullen von wurzel. Diss. Wurzbrug, 1920 apud Leonardo MR, Leal JM. Endodontia: tratamento de canais radiculares. Sao Paulo: Panamericana. 1991. p. 1-18

20. Silva LAB, Assed S, Nelson-Filho P. Protecao Direta da Popa: como fazer e o que utilizar. In: Atualizacao na Clinica Odontologica, Sao Paulo: Artes Medicas. 2002; 2:267-88

21. Leonardo MR, Silva LAB, Leonardo RT, Utrilla LS, Assed S. Histological evaluation of therapy using a calcium hydroxide dressing for teeth with incompletely formed apices and periapical lesions. J Endod 1993; 19(7):348-52.

22. Leonardo MR, Silva LA, Leonardo RT. Devemos usar medicação intracanal no tratamento de dentes com necrose pulpar? In Odontologia Integrada? atualização multidisciplinar para o clinico e o especialista. Rio de Janeiro: Editora Pedro Primeiro Ltda; 1999. p. 179-95.
23. Safavi KE, Nichols FC. Effect of calcium hydroxide on bacterial lipopolysaccharide. J Endod 1993 Feb; 19(2):76-8.

24. Silva LAB. Rizogenese Incompleta-Efeitos de diferentes pastas a base de hidroxido de calciona complementacao radicular e na reparacao periapical em dentes de caes-estudo histologico. Arraquara; 1988 [Dissertacao de Mestrado. Faculdade de Odontologia da Universidade Estadual Paulista].

25. Katebzadeh N, Hupp J, Trope M. Histological periapical repair after obturation of infected root canals in dogs. J Endod 1999 May; 25(5):364-8.

26. Nelson-Filho P, Leonardo MR, Silva LA, Assed S. Radiographic evaluation of the effect of endotoxin (LPS) plus calcium hydroxide on apical and periapical tissues of dogs. J Endod 2002 Oct; 28(10):694-6.

27. Trope M, Delano EO, Orstavik D. Endodontic treatment of teeth with apical periodontitis: single vs. multivisit treatment. J Endod 1999 May; 25(5):345-50.

28. Leonardo MR, Silva LAB, Leonardo RT. Tratamento de canal radicular em sessão ŭnica: crença vs. ciência. In: Feller, Gorab R. Atualização na Clinica Odontolôgica. Sao Paulo: Artes Medicas; 2000. p. 29-57.

29. Dahlen G, Magnusson BC, Moller A. Histological and histochemical study of the influence of lipopolysaccharide extracted from Fusobacterium nucleatum on the periapical tissues in the monkey Macaca fascicularis. Archs Oral Biol 1981; 26:591-8.

30. Barthel CR, Levin LG, Reisner HM, Trope M. TNF-alpha release in monocytes after exposure to calcium hydroxide treated Escherichia coli LPS. Int Endod J 1997 May; 30(3):155-9.

31. Olsen MH, Difiore PM, Dixit SN, Veis A. The effects of calcium hydroxide inhibition on LPS induced release of IL-1b from human monocytes in whole blood. J Endod 1999; 25:289.

32. Jiang J, Zuo J, Chen SH, Holliday LS. Calcium hydroxide reduces lipopolysaccaharide-stimulated osteoclast formation. Oral Surg Oral Med Oral Pathol Oral Radiol Endod. 2003 Mar; 95(3):348-54. 